\title{
We and they in Romans
}

\author{
Bruce J Malina ${ }^{1}$ \\ Creighton University, USA \\ Research Associate: Department of New Testament \\ University of South Africa
}

\begin{abstract}
According to cultural anthropologists ingroup/outgroup divisions are fundamental to Mediterranean views of the world. This essay considers Paul's ingroup/outgroup, or "we/they" perceptions. The ethnocentrism revealed in this dichotomy indicates that Paul, like other Mediterraneans of his time, showed little interest in the outgroup. Not surprisingly, neither was the God of Israel. NonIsraelites simply did not fit into the divine plan of things until non-Israelites, some centuries later, began to identify with Paul's "we" - something Paul did not foresee.
\end{abstract}

\section{INTRODUCTION}

Paul was a Jesus-group prophet (Gl 1:15). By his own admission, he was commissioned to spread God's gospel during an altered state of consciousness (=ASC) experience (G1 1:11-12; cf "by revelation" G1 2:2). He undoubtedly acquired the information that filled the content of that ASC experience from the Israelite Jesus groups he dealt so harshly with as a devoted and zealous Pharisee (Gl 1:13-14). After his call, he says, he went to Arabia and learned how to understand the Jesus story from Jesus groups there (G1 1:17). When he took up the task of spreading God's gospel, he made it quite clear that the world was divided into Israelites and non-Israelite ("the circumcised and the Gentiles" or "Foreskins" [RSV "uncircumcised"] Gl 2:7-8) - the usual ethnocentric perspective shared by other New Testament writings.

\footnotetext{
1 Paper presented at the International Context Group Meeting at the University of Pretoria, June 2001. Prof Dr Bruce J Malina visited South Africa as Research Associate of Prof Dr Pieter F Craffert, Department of New Testament, Faculty of Theology and Religion, Unisa.
} 
While we have no evidence of Paul presenting God's gospel in story form as the Gospels did, we do have his letters, largely concerned about the Jesus groups that he founded. The exception to this last observation is the letter to the Romans, directed to a Jesus group he did not found. It is essentially a letter about travel arrangements, yet largely devoted to an ideological statement with which Paul underscores his ingroup belonging with the Jesus group(s) in Rome to which he wrote.

A number of years ago (Malina 1978), I suggested that a useful way to analyze ancient letters concerning which we lack information about the recipients of the communication is to set out the taxonomy of social groups that the letter writer articulates in the letter. Hence to analyze the perspective adopted by Paul in Romans (and perhaps other letters as well), a first useful tool in social scientific interpretation is to draw up such a taxonomy.

A first set of markers indicating the taxonomy Paul had in mind consists of the ways in which he sets off the inside from the outside, or the ingroup from the outgroup. These markers are indicated by Paul's differentiation of the "we" from the "they." As is well known, the word "we" is either exclusive (I and they, but not you) or inclusive (I, they and you). "They" can refer to non-Israelites and Israelite non-Jesus group members. The word "all" seldom, if ever, refers to some universal everyone, everything or everyplace (e g Rm 1:5 "all nations"; Rm 1:8 "all the world"). It usually marks some discrete entity known from the social or textual context: all the outgroup, all the ingroup, all in Israel - with the qualifying group specified at times, but usually unspecified. Similarly, the word "God" invariably refers to "the God of Israel," since Gentiles have "many gods and many lords" (1 Cor 8:). "Christ," of course, means "Israel's Christ" or Messiah of Israel. The same is true of the rhetorical "man," (e g Rm 2:1.3) which in Romans, for example, means "Israelite man."

My attributions of "Israelite" to these generic pointers presupposes Paul's taxonomic categories rooted in his ingroup. Merely categorizing people as belonging to one group or another produces social discrimination, with members favoring fellow ingroup members and discriminating against the members of outgroups. Such group boundary marking emerges in all of Paul's writings. A well-know boundary marker 
employed by Paul sets off "Judeans" from "Gentiles," that is Israelites from nonIsraelites. This perspective points to Paul as a typical Mediterranean ethnocentric person.

To complete the dimensions of the taxonomic task we would further need a set of tools for understanding social identity, how groups mark themselves off from other groups in terms of social psychology: insider and outsiders (see the excellent presentation by Esler 1998).

And finally we would need a set of tools that talk explicitly about line crossers, the ones who leave groups, break up groups or join groups. The focus on line crossing is not accidental but derives from Paul's own observations. He frequently notes how his fellow Jesus-group members came to those groups, and he is often insistent that group members mark themselves off from outsiders, yet that they be concerned about what outsiders think of them.

This essays deals solely with the first of these tools: Paul's taxonomy, that is, his set of markers delineating the ingroup from the outgroup, "we" from "they"

\section{WE AND THEY - INGROUP AND OUTGROUP}

\subsection{New Testament writings are ethnocentric}

The main Pauline taxonomic category known to New Testament readers, professional and non-professional, is that of "Judean and Gentile" (I treat the translation problem later; “Gentile" does not mean "paganus," a term applied to unbelievers only after Constantine, as pointed out by O'Donnell 1974). This division points to the distinction between ingroup and outgroup persons, between insiders and outsiders. This distinction is a fundamental first-century Mediterranean perspective. It is shared by all New Testament authors, as we discover in their documents.

The boundaries of an ingroup are fluid; ingroups could and did change, at times expanding, at others contracting. Ingroup feelings are rooted in the perception of similarity with others, specifically with one's gender, one's age cohort, one's family, extended family, neighborhood, town or city section and ethnic group. Ingroup members are treated with loyalty, openness, solidarity and support. Persons from the same city quarter or village would look upon each other as ingroup when in a "foreign" location, 
while in the city quarter or village they may be outgroup to each other. Those falling outside the ingroup boundaries are the outgroup. With the outgroup, almost "anything goes." Dealings with outgroup persons are indifferent, even hostile. For practical purposes they are, again, a different species of being. Such binaries such as elite (optimates, patricians) and commoners (populus, plebeians) (see Rm 12:16), male and female, slave and free (see Gl 3:28), city dweller and villager (see Jr 26:16-17), citizen and non-citizen (Ac 22:28), various professions and guilds (Sir 38:24-39:11; Ac 19:24) and the like, are so many ways in which the ancients divided people inside and outside of their societies and thus made sense of that collectivity of human beings that made up their societies.

When Paul views the world as consisting of "Judeans and Gentiles," he not surprisingly articulates the distinction between his ingroup and the outgroup based on ethnicity and rooted in geography. This insider/outsider division is a form of boundary drawing that constitutes a fundamental dimension of a group's purity system, enabling a place for everyone and everything, thus creating order. To say the least, such categorization lends itself to radical ethnocentricism.

Herodotus (8.144.2) defined Hellenic ethnicity in terms of four feature: common blood, common language, common way of life and common worship. Herodotus excludes common geography or territory since he presumes both an immobile population as well as unconcern for outsiders. In Israel these common features were called "ancestral," or "traditional": same ancestors, same language as ancestors used, ancestral customs, ancestral worship and ancestral land. Ties to ancestral land emerge with the Israelite experience of elite exile and emigration. These, of course, are all socially contrived categories used to draw up boundaries and to distinguish "them" from "us." In the ancient Mediterranean, every ethnos was marked by these common, ancestral or traditional features that supported its ethnocentrism.

In point of cultural fact, the New Testament writings are definitely ethnocentric, and the ethnos in question is Israel. The term "ethnocentrism" was coined by William Graham Sumner in 1906: 
Ethnocentrism is the technical name for this view of things in which one's own group is the center of everything, and all others are scaled and rated with reference to it. Folkways correspond to it to cover both the inner and the outer relation. Each group nourishes its own pride and vanity, boasts itself superior, exalts its own divinities and looks with contempt on outsiders. Each group thinks its own folkways the only right ones, and if it observes that other groups have other folkways, these excite its scorn. Opprobrious epithets are derived from these differences .... For our present purpose the most important fact is that ethnocentrism leads a people to exaggerate and intensify everything in their own folkways which is peculiar and which differentiates them from others. It therefore strengthens the "folkways".

(Sumner 1906: 12-13; cited from Reminick 1983:7)

Sumner's phrase "folkways" refers to "ancestral tradition," "tradition of the ancients" in the New Testament documents ("the traditions of my ancestors," ton patrikon mou paradoseon, Gl 1:14; "departed from ancestral traditions," patrion dogmaton, 3 Macc 1:3; "the ancestral tradition of your political life," patrion thesmon, 4 Macc 8:7; "abandon their ancestral custom," patrion ethon, 4 Macc 18:5). All Biblical documents are ethnocentric. And if the documents of the New Testament are anti-anything, they are anti-Gentile, that is , anti non-Israelites. Hence a priori we should not expect to find much about actual non-Israelites in the tradition. The New Testament in general has extremely little to say about Gentiles. No injunction from Jesus has come down expressing concern for Gentiles, or directing a mission to Gentiles.

Paul (like other New Testament writers) always viewed his own group, Israel, as the center of everything. In this he was like any other Israelite writer. Philo, for example, believes Israel is the "most God-loving of all nations," a nation on whom the rest of the human race depends for priestly service and prophecy. He notes that the marriage of Abraham and Sarah "which however was not intended to produce any limited number of sons and daughters - the most God-loving of all nations - and one which appears to me to have received the offices of priesthood and prophecy on behalf of the whole human race" (Philo, On Abraham, 98). All other peoples (this is what "Gentiles" means, Greek: ta ethne; Latin: gentes) are scaled and rated with reference to Israel. 
Israel's ancestral customs correspond with its ethnocentrism and cover relations and behaviors both within Israel as well as toward outsider, "all other peoples." As we see from Paul's writings, Paul shares in Israel's ways of nourishing its own pride and vanity, boasting itself superior, exalting its own ancestral divinity, and looking with contempt on outsiders. Israelites, of course, believe their ancestral customs were the only right ones, indeed taught by "nature" itself (described by the Torah). The ancestral customs of other groups excite its scorn ("against nature"). Opprobrious epithets are derived from these differences. As ethnocentric Israelites, we should expect early Jesus group members, including Paul, to exaggerate and intensify everything in their own ancestral customs which was peculiar and which differentiated them from other peoples. Such exaggeration and intensification vis-a-vis the outgroup served to strengthen the ancestral customs. Since all biblical documents are ethnocentric, if the documents of the New Testament are anti-anything, they are anti-everyone but Israel. Their arguments are ingroup arguments with little, if any, concern for the outgroup - mirroring Israel's beliefs in the concerns of the God of Israel. This ethnocentric orientation is apparent in the categories of peoples with which Paul describes the world.

\section{1 "Judean and Gentile"}

"Judean and Gentile" is a statement of binary opposition, two opposing and incongruous groupings. Ever since the Nakba (the "Catastrophe," the founding of the modern Israeli state) and awareness of how Israeli historians have produced ancient histories in the service of the Zionist agenda (see Bowersock 1988), an increasing number of U.S. biblical scholars have called attention to the prevalent ethnocentric and anachronistic reading of the New Testament in general, and to the inaccuracy of translating the Greek word Ioudaios as "Jew." The more appropriate version of "Ioudaios" is "Judean" (see Miller 1992:193-4; Horsley 1994:398-399; Koester 1994:541-543; Pilch 1997; Von Wahlde 2000; many scholars are not aware of the social dimensions of the problem, cf for example Tomson 1986, 1990; Kraemer 1989, 1991; Williams 1997). The term means "of or pertaining to the people and/or land of Judea; a person following Judean customs and mores; an Israelite emigre." While in Judea, Judeans distinguished themselves from 
Galileans and Pereans, with all three making up the "house of Israel," or "Israel." Outside of Judea, Hellenists referred to Israelites as "Judeans."

Common geographic origin is a further ingroup feature. Being of similar geographical origin meant to harbor ingroup feelings, especially when away from that place of origin and even when long departed from it. For it was the place of origin that endowed group members with distinctive characteristics. This is the fundamental cultural presupposition of the ingroup/outgroup perspective based on ancestral place. Thus Plutarch (On Brotherly Love 19.490, B Loeb) advised:

... when differences arise against brothers, we must be careful especially at such times to associate familiarly (plesiazein) with our brothers' friends, but avoid and shun all intimacy with their enemies, imitating at this point, at least, the practice of Cretans, who, though they often quarreled with and warred against each other, made up their differences and united when outside enemies attacked; and this it was which they called "syncretism" (sygkretismos)"

"Gentile" (Greek: ta ethne) means "peoples," various populations defined by common genealogy. The word is the Israelite ingroup designation for all peoples other than Israel. Thus in Paul's collocation ta ethne means everyone who is not a Judean. These categories are quite demonstrative of ancient Israelite values.

The categories "Judean and Gentile" ${ }^{2}$ underscore the fact that Paul, like other first century Mediterraneans was an ethnocentric person. It was his group, the Judeans/Israel, that stood at the center. All others were peripheral, "naturally" placed outside the center by the God of Israel believed to have created these other peoples along with Israel. Israel is thus the people of peoples, and this by divine disposition, divine ascription (like gender, kinship and kingship). Groups that did not belong within Israel were "the other

\footnotetext{
2 Apart from this collocation (Ioudaioi kai ethne) ethnos has a range of meanings: Liddell Scott offer: company, body of men; a race, tribe; a nation, a people, a particular class of men, a caste; while MoultonMilligan give: province (outgroup, outsiders of city), category (of people), class (of priests), association (of gravediggers), collegium. For example, in Mt 21:43, Jesus directs a threat to chief priests: "Therefore I tell you, the kingdom of God will be taken away from you and given to a nation (ethnos) producing the fruits of it." In context here the term ethnos clearly means a group, caste, company of men, body of men, that would take the place of the present chief priests, as in Is 66:18-21 where all Israel will be gathered from among the nations and ferried in honor to "my holy mountain in Jerusalem."
} 
peoples." "Gentiles," of course, did not know they were Gentiles since they would need an Israelite ethnocentric perspective to learn of their peripheral cosmic and social situation.

To share the same ancestral place of origin meant to harbor ingroup feelings, especially when away from that place of origin and even when long departed from it. For it was the place of origin that endowed group members with particular characteristics. Note, for example, Pliny's ethnocentric perspective. He considered Europe the significant part of the world, and Italy as the center of Europe. Rome, of course, was the center of Italy:

To begin then with Europe, nurse of the race that has conquered all the nations, and by far the loveliest portion of the earth, which most authorities not without reason have reckoned to be not a third part, but a half of the world, dividing the whole circle into two portions by a line drawn from the river Don (Tanaus) to the Straits of Gibraltar (Gadatinum)/

(Pliny, Natural History III.i, §5, Loeb)

And further on:

I am well aware that I may with justice be considered ungrateful and lazy if I describe in this casual and cursory manner a land (Italia) which is at once the nursling and the mother of all other lands, chosen by the providence of the gods to make heaven itself more glorious, to unite scattered empires, to make manners gentle, to draw together in converse by community of language the jarring and uncouth tongues of so many nations, to give mankind civilization, and in a word to become throughout the world the single fatherland of all the races. But what am I to do? The great fame of all its places - who could touch upon them all? and the great renown of the various things and peoples in it give me pause ... The Greeks, themselves a people most prone to gushing self-praise, have pronounced sentence on the land by conferring on but a very small part of it the name of Great Greece!

(Pliny, Natural History III.v, §39-42 Loeb) 
For Pliny "The one race (gens) of outstanding eminence in virtue among all the races in the whole world is undoubtedly the Roman" (Natural History VII.xl, §130, Loeb). To prove it was not difficult. "There is a countless series of Roman examples (of men of intellectual excellence), if one chose to pursue them, since a single race (gens) has produced more men of distinction in every branch whatever than the whole of the other lands (terrae)" (Pliny Natural History VII.xxx, §116 Loeb).

Two generations earlier, Cicero (De haruspicum responsis IX.19, Loeb) too noted that Rome's preeminence was due basically to the moral virtue of its inhabitants:

However good be our conceit of ourselves, conscript fathers, we have excelled neither Spain in population, nor Gaul in force (robor), nor Carthage in cleverness (calliditas), nor Greece in technology (ars), nor indeed Italy and Latium itself in the innate sensibility (sensus) characteristic of this land and its peoples; but in piety, in devotion to religion (pietas et religio) and in that special wisdom which consists in the recognition of the truth that the world is swayed and directed by the disposal of the gods, we have excelled every race and every nation.

The descriptions of Cicero and Pliny go to form the stereotype of Rome held for generations. Consider the 4th century $\mathrm{AD}$ author Vegetius (Epitome 1.1):

The Romans were less prolific than the Gauls, shorter than the Germans, weaker than the Spaniards, poorer and less astute than the Africans, inferior to the Greeks in techniques and in reason applied to human things. But this sort of human had a decisive superiority, a vocation to dominate assured by three factors: the exercise of arms (armorum exercitio), the discipline of the camp (disciplina castrorum), the way of using the army (usus militare). This refined military science suffused with ethics had become the foundation of the daring, the certainness of success and at the same time the peculiar character of the Roman type. 
Romans, in their ethnocentrism, thus thought they were a unique, special people favored by the gods and dwelling at the center of the world. Israel's "chosen peoplehood" is simply another instance of such ancient Mediterranean ethnocentrism.

To return to Paul, his assessment of the world in terms of "Judeans and Gentiles" is typical Israelite ingroup, ethnocentric language characteristic of ancient Mediterraneans. Would Paul's usage be an obstacle to outreach to the Gentiles? Or is such brazenness expected of Judeans? Given this ethnocentric social context, Paul's mission "to the Gentiles" is best understood as a high context phrase meaning "to Israelites dwelling in the geographical regions outside of Judea," which is where some Israelites happened to be. Only when Paul directly addresses "Gentiles" with that pejorative label (e $\mathrm{g} \mathrm{Rm} \mathrm{11:13)} \mathrm{can} \mathrm{we} \mathrm{be} \mathrm{sure} \mathrm{he} \mathrm{is} \mathrm{speaking} \mathrm{to} \mathrm{non-Israelites.} \mathrm{Otherwise} \mathrm{his} \mathrm{Roman}$ audience should be considered totally or nearly exclusively Israelite Jesus group members. There was a large Judean enclave in first century Rome, both before and after Claudius' expulsion of Judeans (54 AD).

And yet, the Roman empire did entail a view that transcended one's ethnos, in a way. This is the assessment of the world in terms of "Greek and Barbarian." Empireminded people were those aware of being part of "the Greco-Roman empire, with its three million and a half square kilometers [as] an island of civilization surrounded by barbarians (Strabo, Geography, end of book 6)" (Veyne 1989:388). In the perspective of these cosmopolitans (which included Romans and other ethnic groups) all civilized people were "Greeks," while the rest were "barbarians" or some other subset known for something other than their level of humaneness. Even Israelites accepted this viewpoint. For example, Philo of Alexandria, when writing of Caesar Augustus' conquests in the Alps and in Illyria, stated how the princeps: "had healed the disease common to Greeks and barbarians ...." (Embassy to Gaius 145, Loeb). What in fact had Augustus done? "This is he who reclaimed every state (polis) to liberty, who led disorder into order, and brought gentle manners and harmony to all unsociable and brutish nations, who enlarges Greece (Hellas) with numerous new Greeces and hellenizes (aphellenisas) the outside world (barbaroi) in its important regions ...." (Philo Embassy to Gaius 147, Loeb). Hence it is not surprising that Paul too gives a passing nod to "Greeks and Barbarians" (Rm 1:14). In Hellenistic perspective, shared by Roman elites, the Barbarians also 
included Israelites. Josephus notes that, "[Apollonius] says that we [Israelites] are the weakest of all the barbarians, and that this is the reason why we are the only people who have made no improvements in human life" (Josephus, Against Apion, II.15, Loeb). Philo (On the Life of Moses II.IV.15) also includes Israel among the barbarians.

Among "Greeks," it would be difficult to distinguish Mediterranean Judean from Mediterranean Gentile. As Shaye Cohen (1999:37) observes: "Jews and gentiles were corporeally, visually, linguistically, and socially indistinguishable."

If, then, circumcision was neither an infallible nor a usable marker of Jewishness; if there were no genealogical records that would have proven who was a Jew and who was not; and if the Jews of antiquity looked like everyone else, spoke like everyone else, were named like everyone else, and supported themselves like everyone else, how did you know a Jew in antiquity when you saw one?

(Cohen 1999:53)

Cohen's observations, based on ancient Mediterranean documents, have little if anything to do with those $8^{\text {th }}$ century central Asian converts to Judaism, the Khazars (also known as Ashkenazi Jews) - people who have, what ancient physiognomic authors called, "northern" features (see Polemo, Physiognonomia, chap 32; see Malina 1992).

Mediterranean Judeans, then, were much like their agonistic neighbors. This, of course, might mask another, more significant set of distinctions. If Judean and Gentile were hard to distinguish, what of ingroup Judean differences? Would it be equally difficult to distinguish a "true Israelite" from those relegated to the periphery of those who thought they were "true Israelites"? What of those Judeans who found grounds to exclude fellow ethnic groups altogether?

As can be seen from the sources, the house of Israel in the first-century world consisted of quite diverse groupings, with no truly unique cultural features aside from ancestral genealogy. Yet there was a configuration of attributes characteristic of Judean Judaism, that is, Judean ancestral customs: endogamy (often called loyalty to family, extended and clan); belief in the God of Israel and in Satan in conflict with this God; 
belief in predestination; belief in ancestral traditions which included standards and norms, varying in quality and degree from region to region, tribe to tribe and status to status; adaptability to changing conditions. The integration of many Judeans into Gentile (nonIsraelite) culture due to settlement, as Cohen intimates, would necessarily dilute many older Israelite cultural values and beliefs. Not all waves of emigration from Judea had the same definition of who and what is "Israel." What may be accepted as "true-Israel" by one group may be Gentile Hellenism (= Greek) to another. ${ }^{3}$ In Paul's day, Israelite cultural values were diverse, with many traditions and customs passing for "ancestral tradition." And nearly all localite Judean groups had their own particular beliefs and tenets. It would be invalid to generalize and oversimplify by giving concrete norms proper to all Israel. Many exegetes and historians retroject the Ben Zakkaist version of Pharisaism in the Mishna and the Rabbinate that emerged in the late $4^{\text {th }}$ and $5^{\text {th }}$ centuries to the period of Paul and his contemporaries, comparing Paul and Rabbinic Judaism, for example.

Despite what some groups may have believed, at the time there was in fact no Israelite community that could acquiesce in the title of the one, "true Israel." As we see from New Testament evidence, the title was still negotiable (arguments in Matthew for true Israel; Rm 2:28-29 “true Judeans"; Rm 9:6 "true Israel”; Rv 2:9; 3:9 “true Judeans").

\section{2 "Judean and Greek"}

"Judean and Greek" is a binary division of Israelites. It is a general division of the house of Israel adopted by Israelites (like the Hebrew - Hellenist division in Ac 6). For "Judeans and Greeks," see Rm 1:16; 2:9,10; 3:9; 10:12; see also 1 Cor 1:24 and passim; Gl 3:28; Col 3:11. This perspective is likewise evidenced in the narrative of Acts (Ac $14: 1 ; 18: 4 ; 19: 10,17 ; 20: 21)$. "Greek," as previously noted, was the general designation for "civilized," living in a Hellenistic way. The opposite of "Greek" was "barbarian." In this collocation as used by Paul, "Judeans" refers to Israelites resident in Judea, Galilee, Perea and nearby "cities" with high Israelite population (Antioch, Damascus,

3 Cf Acts 6:1: "Now in these days when the disciples were increasing in number [in Jerusalem], the Hellenists murmured against the Hebrews because their widows were neglected in the daily distribution." 
Alexandria). Similarly, for an Israelite "Greeks" were Israelites in Roman Hellenistic “cities" with low Israelite populations.

Consider the many ways Israelites might describe themselves. Consider the features of Paul's self-description and the Israelite groups to which the terms point (Phlp 3:5; cf Rm 11:1, see Malina and Neyrey 1996):

- Hebrew: from Israelite heritage, ethnic designation for Israel's ancestral patriarchs, hence all their offspring [modern Italian word for Jews]

- Israelite: offspring of the genealogical line of Jacob/Israel and of his "12" sons; the name of a people, "Israel"(generic ethnicity; a people) [New Testament, Mishnaic, Talmudic name for a people whom Romans and Diaspora Israelites called "Judeans"]

- Benjamin: specific tribal grouping in idealized 12 tribe system. The attributes: Hebrew, Israelite, and of the tribe of Benjamin all point to ancestry, ancestral lineage.

- Pharisee: member of a political religious elective association focused on core values of consumption (tithing, clothing), commensality (food rules) and cohabitation (marriage rules); an instrumental group concerned with Israelite political religion. Members divided their Israelite world into haberim and am ha aretz. The haberim were companions who could consume, share table and cohabit with each other. They formed fictive political groups (haburoth), concerned with the effective implementation of Torah, Israel's political religious charter. For Pharisees, am ha aretz were "natives, people of the land," fellow Israelites who did not practice the ancestral customs assiduously or at all. Pharisee is a reference of ancestral customs.

- Judean: people dwelling in the territorial region called Judea where the Temple of the God of Israel was located; people who followed the ancestral customs of Israel as practiced in Judea; emigre Judeans, i e emigre Israelites. Judean refers to ancestral place of origin.

- Dispersion: from Greek: diaspora: a collective term for emigre Israelites who one day were expected to return to Judea; once expectations of 
return waned, emigres were simply immigrants or resident aliens. The coming of Jesus as Israel's Messiah would refocus attention of Jesus groups (but not Israelite unbelievers) on these emigres and their return, cf Ja 1:1 "James, a servant of God and of the Lord Jesus Christ, To the twelve tribes in the Dispersion." Also 1 Pt 1:1 "Peter, an apostle of Jesus Christ, To the exiles of the Dispersion in Pontus, Galatia, Cappadocia, Asia, and Bithynia, etc (see Elliott 2000:313-14). Dispersion refers to an ancestral group outside ancestral place of origin.

- Greek: means civilized, a characteristic of any person who spoke Hellenistic Greek, followed Hellenistic customs, and shared Hellenistic values and ideals; opposite of barbarian. "[T]here is ample evidence to show that the Romans of the Republic and later were usually content with the term Graecus to denote both ethnic Greeks and Hellenised peoples of non-Greek origin" (Petrochilos 1974: 18). There really were no Greek ethnics in the first-century. What Petrochilos calls an "ethnic" Greek was a person from a specific city (Athenian) or region (Macedonian) from where Hellenism derived. But there were no "Greeks" in any ethnic (same Greek ancestry) nationalistic or political sense. Thus term "Greek" in Israelite contexts was an Israelite ingroup generic designation for Israelite residents outside Judea in Hellenistic areas. John 7:35 is an example: "The Judeans said to one another, "Where does this man intend to go that we shall not find him? Does he intend to go to the Dispersion among the Greeks and teach the Greeks?" The opposite would be "Disperson among the Barbarians" (see 3. Acts and Paul's Categories, below). Among Israelites, "Greek" refers to Hellenized ancestral group members or ancestral groups located in Hellenized poleis.

Outside Judea, Hellenistic peoples called Israelites "Judeans," a term emigre Israelites likewise used of themselves! Thus "Judean and Greek" served as an Israelite selfdesignation for Israelites resident in Judea and Israelites resident outside Judea who were "Greek," speaking Hellenistic Greek, practicing Hellenistic customs and sharing Hellenistic values and ideals. 
Consequently, a set of categories such as: "neither Judean nor Greek, slave nor free, male nor female" (G1 3:28) are all ingroup categories, that is a division of persons to be found within Israel now to be found in Jesus groups. Given that meaning in language derives from social systems, Paul's ethnocentric attitudes and social location within Israelite groups provides no linguistic or semantic evidence that this categorization has to do with Gentiles. Paul's ethnocentrism precludes social systemic concern for Gentiles.

To appreciate these social line drawings and the stereotypes they entail, one must adopt the point of view of the speaker and the way he or she marks off the world. For Paul the world is either Israelite or non-Israelite, with many category divisions within Israel. Not so among non-Israelites, who are all of a piece, "they," or "Gentile sinners." Not only are peoples and groups divided into Israelite and non-Israelite, but also the region or territory in which these people were found. The reason for this is that people were considered part of the land, and influenced by the sky above. The land, water and air, the environment of human groups, was as much part of self-understanding and selfdefinition as personality is for us. The value of airs, waters and places for ethnic qualities was common knowledge among elites, and points of honor among non-elites as well (Hippocrates, Airs, Waters, Places; Strabo, Geography; see Aujac 1966: 270-273). Firstcentury people were not much interested in personality. Personality could change and first century people despised change. No one ever "converts" in the first century (on conversion, see Nock 1933; however they do adopt innovations, see Malina and Neyrey, 1996; Rogers 1983). And even when change happened, the ancients were often selectively inattentive to it in favor of ongoing similarity.

Paul had an ASC experience through which he was commissioned as an Israelite prophet. From his prophetic role, he appropriated the status and function of Jesus-group apostle with the task of proclaiming God's gospel of Jesus as Israel's Messiah and cosmic Lord. Just as ethnocentric Israel divided the world into Israel and non-Israel, there were Israelites resident in predominantly Israelite populations, "the Circumcision," and those resident among predominantly non-Israelite populations, "the Foreskins" (RSV: "uncircumcision;" the Greek is akrobystia, which means "foreskin"). Calling the outgroup, "Foreskins," is another ethnocentric, boundary marking ploy. Paul believed his commission was to proclaim God's gospel to Israelites resident among the Foreskins. In 
the framework of Galatians, Paul attests that Jesus' ingroup apostles (e g Peter) were to proclaim God's gospel in regions of the Circumcised, regions with large Israelite populations (Judea, Samaria, Galilee, Perea and cities such as Antioch, Damascus and Alexandria). Paul, on the other hand, would do the same in the regions of the Foreskins, regions with sparse Israelite populations (the circuit from Jerusalem to Illyricum, Rm 15:19). About Foreskin regions, as Feldmann (1933:73) has noted: "The relative lack of contact between the Jews [sic] of Asia Minor and the fountainhead in the Land of Israel may explain why Christianity [sic] seems to have made relatively great progress in Asia Minor, presumably among Jews [sic] by the beginning of the second century."

I think it is very important to note that according to this notice in Rm 15:19, Paul finished his original commission to "all the Gentiles," and now felt he had to move on, through Rome to Spain. If his charge were to proclaim mainly and directly to nonIsraelites, it is hard to believe (perhaps impossible to believe) that he would have already finished the task!

\section{3. "JUDEAN," GENTILE AND ROMANS}

Consider, now, Paul's letter to the Romans. Given the ethnocentric categories employed by Paul, the problem that the letter to the Romans poses for the interpreter is to underscore specifically to whom the letter to the Romans was written. What is curious about the letter is that nowhere does it mention Roman personages, or "Romans." Rather it speaks of "God's beloved in Rome." The question, then, is who were these beloved of God in Rome? As an Israelite designation, it would mean Israelite or Judean minority resident among a Roman majority population. The God involved would be the God of Israel. From the rest of the letter we know Paul is addressing a Jesus group resident among a Roman majority (by the time of Constantine, as can be determined from archaeological sites, there were 7000 Jesus group adherents in Rome!).

As one will find in most commentaries, there are at least two views about Paul's Roman audience just as there are about most features of Pauline study. Fitzmyer reports as follows: One view, the older modern view (Tübingen School, E Renan, T Zahn, W Manson, F Leenhardt), holds that Paul's audience consisted of "Jewish Christians," that is Jesus group members of Israelite origin. The newer modern view (J Munck, S Lyonnet, 
O Michel, C K Barrett, J Fitzmyer) holds that Paul's audience was "Gentile," that is people other than Israelites, non-Israelites. Fitzmyer (1969:292) concludes: "But the question is really insoluble and somewhat idle, for a close scrutiny of the letter shows that Paul is not aware of the concrete situation in Rome and is not coping with specific problems of the Roman church that may have been reported to him."

Fitzmyer is, of course, innocent of the fact that meanings come from social systems. While Paul may not be aware of the concrete situation in Rome, he does claim that he knew the generic situation in Rome; the "faith" of God's beloved in Rome "is proclaimed among [Jesus groups] throughout the whole world" (Rm 1:8). This "faith" is what constituted this group as a group, hence it refers to its shared values and interpersonal behaviors. It is on the basis of this information that Paul feels free to send this letter. The goal of the letter is to present a request for hospitality $(\mathrm{Rm} \mathrm{1:10;15:24)}$ to be

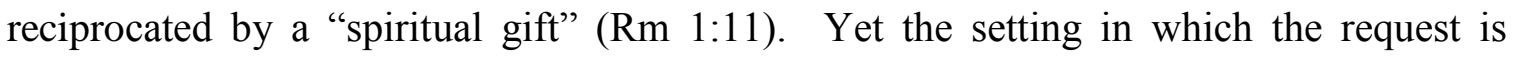
presented is a long discourse intended, presumably, to demonstrate that Paul in fact does belong with "God's beloved in Rome." The letter to the Romans is a sort of "captatio benevolentiae" directed to those with whom Paul hopes to spend some time. The ideology he articulates is to resonate with the ideology that holds the Roman Jesus group together.

While Paul may not be aware of the concrete situation in Rome, he is presumably a considerate author. That means he takes his readership and/or audience into account in what he says and how he says it. He presumably seeks to make sense. From the perspective of the prevailing Mediterranean ethnocentrism, the historical question is: to whom would the message and method of Romans make sense: Israelites, non-Israelites or both? One must decide since this letter of Paul's, like the rest of his letters, is extremely high context. He leaves much unsaid and presupposes a social system that provides general meanings and orientations for himself and his audience (if an audience is implied in all of Paul's letters, this holds a fortiori for Romans).

Recently Stowers (1994) and Gager (2000) after him have argued that Paul's implied audience in this letter were totally Gentiles, that is non-Israelites (for an opposite view, see Mason 1990; Nanos 1997). They claim that this is rather obvious. For example: "From beginning to end, Romans presupposes an audience that consists of 
gentiles who had or still have a lively interest in Judaism. Such people existed and most likely made up the bulk of the early gentile converts to Christ" (Stowers 1994:277 and passim). They then proceed to read Romans as a document directed to non-Israelites, although in fact they offer no evidence for a Gentile readership apart from their insistent presupposition or presumption.

Paul's statements are high context, and thus allow for such a reading. Yet the most one can say is that "if" Paul were writing to non-Israelite Jesus group members in Rome, then Romans would sound to them like Stowers and Gager's reading. But what evidence is there for this? Gager seems motivated by political correctness (Paul does not require "Jews" to convert at all, ever), and Stowers looks to thwarting Christian antiJudaism which he ascribes to a wrongheaded reading of Paul.

I, on the other hand, am motivated by "irrelevance." One of my criteria for an adequate historical interpretation of the New Testament is that the meaning of the document should be of little direct and immediate relevance to the twenty-first century. Twenty-first century "political correctness" would discount the Israelite audience, since that would make it relevant for today. Furthermore, I cannot understand how an ancient Israelite or modern Israeli can be "anti-Semitic" (unless all of Israel's biblical prophets are anti-Semites for criticizing Israel so viciously?).

\subsection{Paul's Use of Israel's Scripture}

The abundant use of explicit and implicit quotations from Israel's Scriptures, along with references to the Ten Commandments, the Abraham story, the Exodus and the like indicate that Paul envisaged his audience in Rome to be largely Israelite. Stanley (1999) has recently demonstrated the inadequacy of many assumptions made by modern scholars about Paul and his use of Scripture. Stanley's critique is based upon a presupposition that Paul's audiences were largely non-Israelite. However if these audiences were predominantly Israelite, many of his disavowed assumptions would, in fact, be quite accurate. Presuming Paul were a considerate author, given how he writes and cites Scripture in Romans and elsewhere, we can surely hold, contrary to Stanley, that: 
- Paul presumed that his audiences were socialized into Israelite Scriptures, whose stories served as their intertext; they were not alien to the general contents of these books.

- He expected his audiences to acknowledge the authority of Israelite Scriptures as a source of truth and a basis for arguing about proper conduct.

- As considerate speaker/writer, Paul assumed his audiences were able to recognize Scriptural stories and to appreciate an argument based on quotations from Israelite Scriptures.

- Paul's audiences could supply for themselves many dimensions of Israelite Scriptural stories, but they perhaps could not supply the background and context of many of Paul's quotations, allusions, and other references to Israelite Scriptures.

- Paul expected his audiences to recognize, respect, and appreciate his abilities at talking "Bible," that is at making frequent implicit allusions to Israelite Scriptures.

- The best way to define the Pauline "meaning" of a biblical quotation is to study how Paul and other Judean emigre community authors used and interpreted the biblical text.

On the other hand, we can agree with Stanley that Paul and his audiences did not have free access to the Greek translation of Israelite Scriptures (the "LXX"). In other words, they could not study and consult them whenever they wished. Similarly, it is obvious that Paul himself knew and took into account the context of his biblical quotations as interpreted by the literate Judean emigres among whom he was socialized. Paul's use of Israelite Scriptures, then, points to an Israelite audience. Using the Scriptures would make little impact on non-Israelites ( $\mathrm{cf}$ use of Vedas or the Qur'an to make points with modern Christians).

In sum Paul's use of Israel's Scriptures points, by and large, to an Israelite audience. Paul's going "to the Gentiles" is a high context way of expressing his going to Israelites among the Gentiles. Such high context usage is not odd. I head an Israeli bond salesmen tell a group of Omaha Jews that he is sorry to leave, but must address other Americans (meaning Jews in America, of course). And a Nigerian student, resident in the 
U S. for several years, once told me that "we do not speak to foreigners" (meaning nonNigerian U S residents).

\section{ACTS AND PAUL'S CATEGORIES}

The author of Acts confirms Paul's categories. While doubts about the historical accuracy of Acts speckle Luke's reports about Paul, I believe that the fundamental and general perception of values, persons and categories imparted by the author of Acts are the values, persons, and categories shared by Jesus groups in the Eastern Mediterranean. Of basic importance for this essay is the pattern followed by Paul in his outreach to fellow Israelites. He goes to synagogues or Israelite enclaves in every Foreskin "city" to proclaim God's gospel about Jesus. Consider how Luke describes these Judeans from among the Foreskins in Acts 2:5-11:

2:5 Now there were dwelling in Jerusalem Judeans, devout men from every people (apo pantos ethnous) under heaven.

2:6 And at this sound the multitude came together, and they were bewildered, because each one heard them speaking in his own language.

2:7 And they were amazed and wondered, saying, "Are not all these who are speaking Galileans?

2:8 And how is it that we hear, each of us in his own native language?

2:9 Parthians and Medes and Elamites and residents of Mesopotamia, Judea and Cappadocia, Pontus and Asia,

2:10 Phrygia and Pamphylia, Egypt and the parts of Libya belonging to Cyrene, and visitors from Rome, both Judeans and proselytes,

2:11 Cretans and Arabians, we hear them telling in our own tongues the mighty works of God.

I find it significant that in this passage, Parthians, Medes, Elamites, Mesopota-mians, Cappadocians, Pontians, Asians, Phrygians, Pamphyians, Egyptians, Cyreneans, Cretans and Arabs are all "Judeans." In Acts, Paul goes "to every Gentile people" and seeks out 
these Judeans! After all, from an Israelite ethnocentric perspective, why would the God of Israel care about non-Israelites - except to have them applaud what the God of Israel does for his own people?

Consider, further, Luke's collocation of Judean and Greek. There is no passage in which "Greek" univocally points to non-Israelite or Gentile! The episode of the disciple Timothy, "the son of a Judean woman who was a believer; but his father was a Greek" (Acts 16:1) whom Paul circumcised because of complaints by Judeans simply indicates that some Hellenized Israelites were not in habit of circumcising (see McEleney 1973, 1973/4, 1978); the same would be true of Titus (G1 2:3). Of course Luke's mention of "a synagogue of the Judeans" (Ac 14:1) would be a tautology unless there were also synagogues of the Greeks (as there were in Jerusalem e g Act6:9: "Then some of those who belonged to the synagogue of the Freedmen (as it was called), and of the Cyrenians, and of the Alexandrians, and of those from Cilicia and Asia, arose and disputed with Stephen"). There were Judeans and Greeks regularly in the synagogues in which Paul spoke (Ac 14:1; 18:4). Mention of Judeans and Greeks hearing the word of the Lord in all of Asia (Ac 19:10) and in Ephesus (19:17) is quite ambiguous for two reasons. First, Israelite residents in Asia or Ephesus would be called Greeks, and secondly, to "testify both to Judeans and to Greeks of repentance to God and of faith in our Lord Jesus Christ" (Acts 20:21) would make little sense to Gentiles. Only Israelites could and needed to repent. Finally even the Jerusalemite Jesus group members who attest to "many thousands of Judeans ... who have believed" worry about their reaction to Paul who "teaches all the Judeans who are among the Gentiles to forsake Moses"(Ac 21:21). The point is that while some Gentiles did join Paul's Jesus groups, his mission was to "all the Judeans who are among the Gentiles."

In general, Acts agrees with Paul's assessment of his task and is equally ethnocentric in its view of the Mediterranean world.

\section{CONCLUSION}

Social scientific approaches to the New Testament make it increasingly bewildering to find people arguing about "anti-Semitism" (sic) in the New Testament. In point of historical, cultural fact, the New Testament writings are definitely ethnocentric, and the 
ethnos in question is Israel. All Biblical documents are ethnocentric. And if the documents of the New Testament are anti- anything, they are anti-Gentile.

Americans were irate when the Ayatullah Ruhullah Khomeini $(\mathrm{PBUH}=$ Peace Be Upon Him) dubbed the U S "the Great Satan." Yet these same Americans attend church where they hear Matthew's gospel in which the greatest ingroup insult is to be called a "Gentile" - which these Americans are! Selective inattentiveness to Israelite ethnocentrism in the New Testament seems to be due to total Gentile ethnocentrism - treating the Bible and the world as though it were for Gentiles. Thus Gentile Bible readers read, for example, about "the meek inheriting the (Holy) land" and refer it to the earth, or about the calamities striking the "land (of Israel)" in the scenario of Revelation 4-11 and take it to mean the whole earth!

To restore a first-century perspective to New Testament Bible reading is to realize that Paul, like his fellow Israelites, was quite ethnocentric and anti-Gentile to a greater or lesser degree. He divided the world into Israelites and all other peoples. Such perception is essentially and fundamentally ethnocentric in a way difficult for persons enculturated in a multicultural democracy to imagine. But it is not difficult to experience in a "master race democracy" like the recent state of Israel, with its recurrent sense of trumped up victimization, of arrogance, of superiority and of entitlement. These Israeli values, rooted in its mythical ethnic story and expressed through its apartheid social structure, are perhaps characteristic of all apartheid, ethnocentric groups (e g Amana colonies, recent immigrant enclaves, Orthodox Jewish neighborhoods in New York, Chicago or Los Angeles).

\section{Works Consulted}

Aujac, G 1966. Strabon et la science de son temps: Le sciences du monde. Paris: Belle Lettres.

Bowersock, G W 1988. Palestine, ancient history and modern politics, in Said, E \& Hitchens, C (eds), Blaming the Victim: Spurious scholarship and the Palestinian question, 181-91. London: Verso.

Buell, D K 2000. Ethnicity and religion in mediterranean antiquity and beyond. Religious Studies Review 26(3, 243-9. 
Cohen, S J D 1999. The Beginnings of Jewishness: Boundaries, varieties, uncertainties. Berkeley: University of California Press.

Elliott, J H 2000. I Peter: A new translation with introduction and commentary. New York: Doubleday. (Anchor Bible 37B).

Esler, P F 1998. Galatians. London: Routledge.

Feldmann, L H 1993. Jew and Gentile in the ancient world: Attitudes and interactions from Alexander to Justinian. Princeton: Princeton University Press.

Fitzmyer, J A 1968. The letter to the Romans, in Brown, R E, Fitzmyer, J A \& Murphy, R E (eds), The Jerome Biblical Commentary, II, 291-331. New York: PrenticeHall.

Gager, J 2000. Rethinking Paul. Oxford: Oxford University Press.

Horsley, R A 1994. The death of Jesus, in Chilton, B \& Evans, C A (eds), Studying the historical Jesus: Evaluations of the state of current research, 395-422. Leiden: Brill.

Koester, H 1994. The historical Jesus and the historical situation of the Quest: An epilogue, in Chilton, B \& Evans, C A (eds), Studying the historical Jesus: Evaluations of the state of current research, 535-45. Leiden: Brill.

Kraemer, R S 1989. On the meaning of the term "Jew" in Graeco-Roman inscriptions. HTR 82, 35-53.

Kraemer, R S 1991. Jewish tuna and Christian fish: Identifying religious affiliation in epigraphic sources. HTR 84, 141-62.

Malina, B J 1978. The social world implied in the letters of the Christian Bishop-Martyr (Named Ignatius of Antioch), in Achtemeier, P J (ed), SBL 1978 Seminar Papers, Vol II, 71-119. Missoula: Scholars Press.

Malina, B J 1992. Is there a circum-mediterranean person: Looking for stereotypes. BTB 22, 66-87.

Malina, B J 1994. 'Let Him deny Himself' (Mark 8:34//): A social psychological model of self-denial. BTB 24, 106-19.

Malina, B J \& Neyrey, J H 1996. Portraits of Paul: An archaeology of ancient personality. Louisville: Westminster/Knox. 
Mason, S 1990. Paul, classical Anti-Judaism, and the letter to the Romans, in Hawkin, D $\mathrm{J} \&$ Robinson, T (eds.), Self-definition and self-discovery in Early Christianity, 181-223. Lewiston, NY: Mellen.

Miller, R J (ed) 1992. The complete Gospels: Annotated scholars version. Sonoma: Polebridge Press.

Nanos, M 1997. The mystery of Romans. Minneapolis: Fortress Press, 1997.

Nock, A D 1933. Conversion: The old and the new in religion from Alexander the Great to Agustine of Hippo. London: Oxford Univ. Press.

O’Donnell, J J 1974. The demise of paganism. Traditio 35, 45-88.

Petrochilos, N 1974. Roman attitudes to the Greeks. Athens: Kovanis.

Pilch, J J 1997. Are there Jews and Christians in the Bible? HTS 53, 119-25,

Reminick, R A 1983. Theory of ethnicity: An anthropologist's perspective. Lanham: University Press of America.

Rogers, E M 1983 Diffusion of innovations. 3rd ed. New York: The Free Press.

Stanley, C D 1999. "Pearls before swine": Did Paul's audiences understand his Biblical quotations? NT 41(2), 124-44.

Stowers, S K A 1994. Rereading of Romans: Justice, Jews, and Gentiles. Hartford: Yale University Press.

Sumner, W G 1906. Folkways: A study of the sociological importance of usages, manners, customs, mores, and morals. Boston: Ginn..

Tomson, P J 1986. The names Israel and Jew in Ancient Judaism and in the New Testament. Bijdragen 47, 120-40; 266-89.

Tomson, P J 1990. Paul and the Jewish Law: Halakha in the letters of the apostle to the gentiles. Assen: Van Gorcum; Minneapolis: Fortress Press. (CRINT 3/1.)

Veyne, P 1989. 'Humanitas': Romani e no[i], in Andrea Giardina (ed), L'uomo Romano, 385-415. Bari: Laterza.

Von Wahlde, U C 2000. "The Jews" in the Gospel of John: Fifteen years of research (1983-1998). ETL 76, 30-55.

Williams, M H 1997. The meaning and function of Ioudaios in Graeco-Roman inscriptions. ZPE 116, 249-67. 